ILIJA MIKIĆ

Institute of Archaeology,

Belgrade, Serbia

mikicilija82@gmail.com
902.2:572.73(497-15)

904:726.8"653"(497-15)

COBISS.SR-ID 219297292

Original research article

Received: July 10th 2015

Accepted: November 15th 2015

\title{
OSSA VORAMINA IN REGIONE BREGMAE PARS SECUNDA-MEDIUM AEVUM
}

\begin{abstract}
As an extension to the Pars Prima-Viminacium, this paper includes another four examples of bones inserted in skull sutures, originating from different sites, just a single example from Serbia and from, what are today, neighbouring states. These include Bisko/Poljanice near Sinj, Arnautovici near Visoko and from the monastery necropolis of Turdoš near Trebinje. One of the two medieval skulls from Lepenski Vir is also included. There are no other medieval inserted skull bone finds in Serbia.

With two cases - Bisko/Poljanice and Arnautovici i near Visoko, there were no problems in positioning the bregma measuring point (B). According to the methodological rules of biophysical anthropology, on the remaining two skulls - from the Tvrdoš monastery and on one skull from Lepenski Vir, the B point was gained only after using the graphical drawing method.
\end{abstract}

KEYWORDS: THE GREAT MIGRATION, THE MIDDLE AGES, VIMINACIUM, BISKO/POLJANICE, ARNAUTOVIĆI/VISOKO, LEPENSKI VIR (MEDIEVAL SKULLS), TVRDOŠ/TREBINJE, OS SUTTURAE SAGITALIS, OS SUTTURAE CORONALIS, OS BREGMATICUM.

\section{INTRODUCTION ${ }^{1}$}

In the previous paper of the same title, but with the subtitle - Pars Prima - Viminacium, typical cases from this site were presented, and this is now in the final stage before publishing. It was established that the typical Os bregmaticum was discovered only on one female skull (G2-97), dat-

1 The article results from the project: IRS - Viminacium, Roman city and military legion camp - research of the material and non material culture of inhabitants by using the modern technologies of remote detection, geophysics, GIS, digitalisation and $3 D$ visualisation (no 47018), funded by the Ministry of Education, Science and Technological Development of the Republic of Serbia. ing from the Great Migration. According to the anthropological finds from Viminacium, eight further skulls were presented in the same paper. They possessed inserted bones in the bregma region (B - the meeting point of the coronal suture and the sagital suture). All of them originate from the archaeologically excavated cemeteries at "Pećine" and "Više Grobalja", both of which form parts of one large southern Viminacium cemetery ( Korać and Golubović 2009; Mikić I. 2013).

Pars Secunda-Medium Aevum is partially based on the anthropological documentation of Ž. Mikić (retired professor from the Philosophical faculty in Belgrade), who did not manage to fully examine and publish them since they originate 
from, what are today, independent states.

According to the aforementioned bequested documentation, these are the finds of typical skulls from the sites of Bisko/Poljanice near Sinj and from the monastery necropolis of Tvrdoš near Trebinje. The third find of an inserted skull bone originates from Lepenski Vir (one out of two finds), previously unpublished. The find from Arnautovići near Visoko was published in 1995 (Hošovski 1995).

\section{MATERIAL AND METHOD}

In the publication of 1995 (Hošovski 1995) regarding the anthropological finds from the medieval necropolis of Arnautovići/Zidine near Visoko, among the epigenetic elements on skulls, there is only a single find of sutura metopica on female skull number 53 (pp. 14). It is remarked that, due to the poor and incomplete skeletal preservation, the author was not able to perform an analysis of epigenetic elements and use the possible results as markers for the examined population group. In accordance with the content paper, skull number 22 is of interest. It should be added that it comes from a necropolis which lay partially under monumental grave-stones, so-called stećci (pp. 11) and that it had a brachicranial medieval population (pp.13). Skull number 22 belongs to a male at the age of senilis (see Table II).

Next in order is the late medieval necropolis of Bisko/Poljanice, actually Poljanice near the village of Biska in Cetinska Krajina, in the Dinaride mountains (Milošević 1991). In this paper, only skull number $5 / 2$ will be presented. It belongs to a male at the age of maturus/senilis (Table II).

The third skull in our analysis comes from Lepenski Vir, although from the Middle Ages (Nemeskeri 1972). Only two skulls of this kind have been discovered, but only one here is of interest to us. This is skull number 30. It belongs to a male at the age of maturus (Table II).

Among the anthropological context of the Tvr- doš monastery near Trebinje, there is skull number 65. It was separated from the osteological material, which has been partially published (Mikić Ž., 2001). It comes from a mass burial with at least seven skeletons. It belongs to a male at the age of adultus/maturus (Table II).

The methodology applied to the four medieval skulls from the sites of Arnautovići/Visoko, Bisko/ Poljanice, Lepenski Vir and the Tvrdoš monastery near Trebinja, is within the standardised criteria of modern biophysical anthropology. Therefore, gender and individual biological age were determined according to the methodological rules determined by V. Bass (Bass 1971), but also according to the handbook of European anthropologists (Ferembach, Schwidetzky and Stloukal 1980). Osteometric parameters were taken according to the standardised definitions of R. Martin (Martin and Saller 1957) and V. Bass (Bass 1971).

Finally, epigenetic analysis was performed according to the method defined in 1967 by A. C. Berry and R. J. Berry (Berry and Berry 1967), initiated as non-metric elements on skulls in 1959 by D. Brothwell (Brothwell 1959). Certainly, more recent publications were also included, such as that of G. Hauser and G. F. De Stefano (1989).

\section{RESULTS}

The goal of our paper was not to report on common os suturae coronalis (see Table I), nor on the typical os bregmaticum. As far as we know, the deltoid os bregmaticum was discovered only among the Gepidae population (Kazanski, Ivanišević and Mastikova 2006) in Viminacium (see Table I). Our attention was focused on specific joint bones located in the region of the coronal joint, regardless of size.

Among the four cases (illustrated in Table II), due to the very difficult identification caused by concrescence (obliteration) of the suturae, we abandoned the alphabetical order used when introducing the material. As a result, the starting 
point was skull number $5 / 2$ from the site of Bisko/ Poljanice.

The inserted bone in the meeting point of the two large joints on the skull from the medieval necropolis of Poljanice near Bisko, close to Sinj, is $1 \times 2 \mathrm{~cm}$ in size (see Table II). Due to its irregular shape, it is very difficult to tell whether it moved the sagital joint into the zone of the frontal bone. The same is true of the skull from Arnautovići near Visoko. On skull number 22, the position, shape and size of the inserted bone are very similar to the Bisko/Poljanice case. The old age (senilis) of this skeleton, together with the obliteration and poor state of preservation, meant that its inserted bone was somewhat difficult to notice. It should be mentioned that there is a big difference between anatomic samples and human osteological material from archaeological sites. Nevertheless, our comment holds true for the previous case: it is very difficult to say whether any movement of the sagital joint in the os frontale region occurred (Table II).

One of the two medieval skulls from Lepenski Vir possesses an inserted bone in the bregma region, with a size of $2 \times 4 \mathrm{~cm}$. It is of a square shape and moved the sagital joint about $1 \mathrm{~cm}$ into the region of the frontal bone (see Table III). However, we should mention that from Lepenski Vir, there are about one hundred skeletons from the Mesolithic and Proto-Neolithic period, as well as that Lepenski Vir is an eponym for a prehistoric culture, so no literature will be listed here.

Skull number 65 from the necropolis of the Tvrdoš monastery near Trebinje was not previously published. By 2001, the material from 21 graves had been published, as well as from four tombs (Mikić Ž. 2001). Grave number 65 consisted of two graves: 65 and 65A. As can be seen from the preserved anthropological documentation, grave number 65 contained only a single robust male skeleton with no pathological changes. It was noted that on the skull, there was an inserted bone (a bone between two joints).

Grave number $65 \mathrm{~A}$ belongs to a mass burial in
Tvrdoš which contained at least six incompletely preserved skeletons, one of which was an infant. The age of the other skeletons was between 30 and 60 years. In Tvrdoš, a total of 74 graves were examined, containing 103 skeletons: 92 adults and 11 infants. This information is not surprising, since in monasteries, only the "chosen ones" were buried. However, in this entire medieval series, only skull number 65 possessed an inserted bone in the bregma region.

As the illustration in Table II shows (bottom right), this inserted bone is of an approximate size of $2.5 \times 2.5 \mathrm{~cm}$, shaped more like the posterior fontanelle bone (fontanelle posterior). It is obvious that this bone penetrated the os frontale with its frontal third.

\section{DISCUSSION AND CONCLUSION}

As mentioned before, the os suturae sagitalis and os suturae coronalis were not presented in this paper, with the remark that a large and typical deltoid os bregmaticum was discovered only in the Gepidae population from Viminacium (see Table I). Four skulls were illustrated in Table II, with some doubts regarding the positioning of the inserted bone. They can more easily and precisely be positioned on the skull during anthropological measuring than on the two remaining skulls (the medieval one from Lepenski Vir and from the Tvrdoš monastery near Trebinje).

There is no need to speak about the frontal and the rear fontanelle (fontanelle anterior and fontanelle posterior) during embryonic or later development, since this has been discussed in detail in different medical text-books and in many different languages. We want to avoid repetition and need to directly present our results.

Page 444 of the anthropological hand-book by R. Martin (Martin and Saller 1957), which is not the only one of its kind, clearly states that when there is an os bregmaticum, there is also a linear extension of the suturae sagitalis and suturae 
coronalis. This is how, graphically, the bregma point (B) is obtained, which is needed in order to determine the height of each skull. In our cases, this represents the skulls from Lepenski Vir and Tvrdoš.

These skulls do not possess a typical deltoid bone on the bregma, especially the two aforementioned skulls. With the other two skulls, the bregma point was found in the described way. This is why it is necessary to graphically mark the tops of both the skull from Lepenski Vir and from Arnautovici and the direction of both the coronal and the sagital sutura. The inserted bones would then show a marker representing the bregma point. We will not be doing this graphical reconstruction on the original finds, in order to preserve their authenticity. One reason for this is the lack of their osteometry.

Finally, it should be added that we also decided to include finds that originated outside Serbia, since, as is stated by Hauser and De Stefano (1989: 96), with medieval Serbs, S. Živanović also did not encounter additional bones in the bregma region. The goal was to collect all of the samples with this kind of anatomic variation from the Balkan area and to present it together.

\section{BIBLIOGRAPHY}

Bass, V. 1971

Human osteology, Missouri: Archaeological Society.

Berry, A. C. and Berry, R. J. 1967.

Epigenetic variation in the human cranium, $J$. Anat., 101: 361-379.

\section{Brothwell, D. R. 1959}

The use of non-metrical characters of the skull in differentiating populations, in: Bericht G. Taggung deutschen Gesselschaft fur Anthropologie,

Kiel: 103-109.
Ferembach, D. Schwidetzky, I., and Stloukal, M. 1980

Recommendations for age and sex diagnoses of skeletons, Journal of Human Evolution 9: 517547.

\section{Hauser, G. and De Stefano, G. F. 1989}

Epigenetic variations of the Human Skull, E. Schweitzertbert' che Verlag, Stuttgart.

\section{Hošovski, E. 1995.}

Rezultati paleopatološke i paleodemografske analize srednjovekovne nekropole Zidine/Arnautovići ( kod Visokog ), Užički zbornik 24: 11-20.

Ivanišević, V., Kazanski, M., and Mastykova, A. 2006

Les necropoles de Viminacium a l'epoque des grandes migrationes, Paris: College de FranceCNRS, Centre de Recherche d'Historie et Civilisations de Byzance.

Korać, M. i Golubović, S. 2009.

Viminacium-Više Grobalja, Beograd: Arheološki institut.

Martin, R. and Saller, K. 1957

Lehrbuch der Anthropologie, Bd. I, Stuttgart: Gustav Fischer.

\section{Mikić, I. 2014}

Viminacium-experiences with human osteological materials, Archaeology and Science 9: 59-66.

\section{Mikić, Ž. 2001}

Antropološki sadržaj crkve uspenja Bogorodice u Tvrdošu, u: Vestigatio Vetustatis Aleksandrini Cermanović-Kuzmanović, Beograd: Centar za arheološka istraživanja Filozofskog Fakulteta u Beogradu: 309-321.

\section{Milošević, A. 1991}

Stećci i Vlasi i njihove migracije 14. i 15. stoljeća, Split: Republički zavod za zaštitu spomenika. 


\section{Nemeskeri, J. 1972}

The inhabitants at Lepenski Vir, in: Lepenski Vir, D. Srejović (ed.), London: Thames and Hudson.

\section{REZIME}

\section{OSSA WORMIANA IN REGIONE}

BREGMAE

\section{PARS-SECUNDA-MEDIUM AEVUM}

KLJUČNE REČI: SREDNJI VEK, BIOFIZIČKA ANTROPOLOGIJA, BISKO / POLJANICE, ARNAUTOVIĆI / VISOKO, LEPENSKI VIR (SREDNJOVEKOVNE LOBANJE), TVRDOŠ / TREBINJE, OSSA WORMIANA, UMETNUTE ILI PREKOBROJNE KOSTI LOBANJSKIH ŠAVOVA.

Umetnute kosti ili prekobrojne kosti lobanjskih šavova (Ossa Wormiana) od svih epigenetskih elemenata najređe se pojavljuju. Prema raspoloživoj literaturi, u regiji merne tačke Bregma (B), kod srednjovekovnih Srba nisu konstatovane. Kada se radi o srednjem veku i širem području Zapadnog Balkana, osim jedne slovenske lobanje sa Lepenskog Vira, tzv. umetnute kosti su uočene na još dve lobanje u Bosni i Hercegovini i na jednoj u Hrvatskoj. To su: manastir Tvrdoš kod Trebinja, Arnautovići kod Visokog i Bisko, odnosno Poljanice u Cetinskoj Krajini. Svi pobrojani nalazi su prikazani na odgovarajućim fotografijama, pošto predstavljaju specifične nalaze u oblasti biofizičke antropologije, a inače se vrlo retko nalaze na lobanjama iz različitih perioda. 

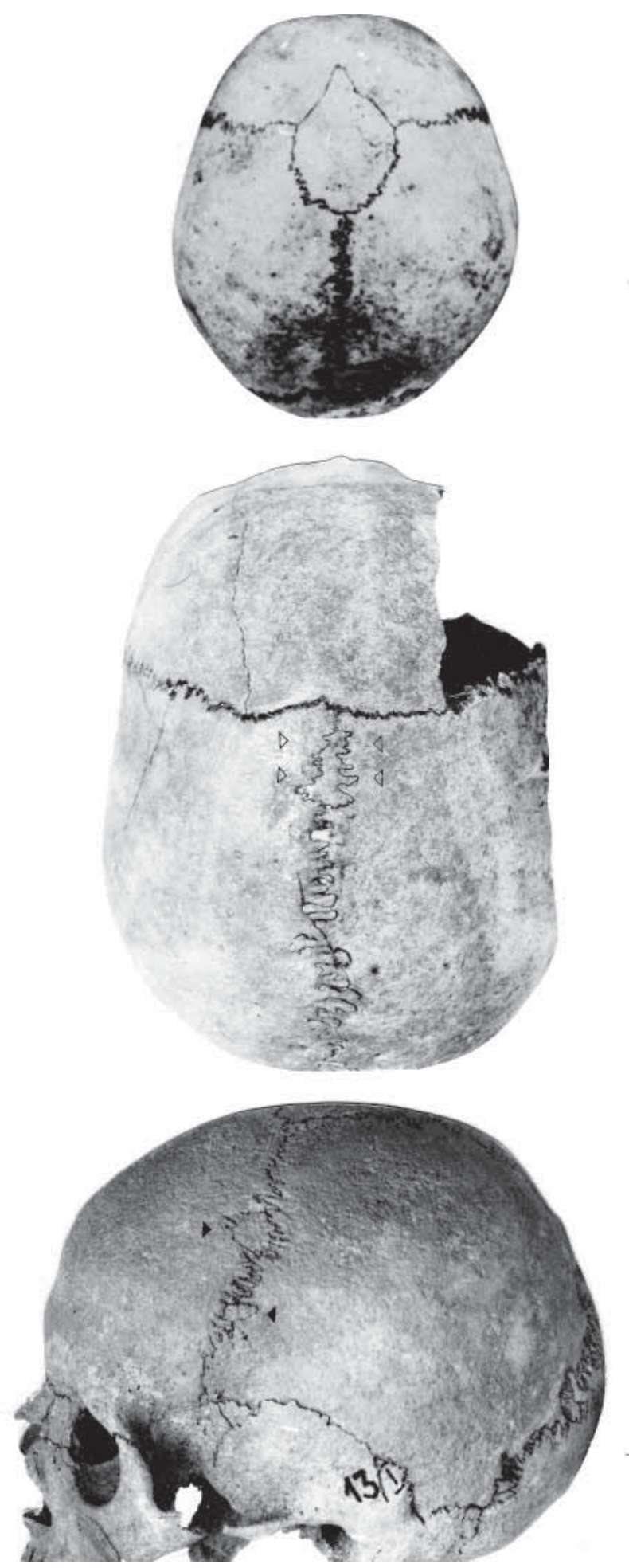

Os Bregmaticum Viminacium/necropolis Više Grobalja G2-97 Os suturae sagitalis/Vinča-Beli Breg/br 90

Os suturae coronalis/Viminacium/necropolis Nad Lugom br. 13/1

Table I 


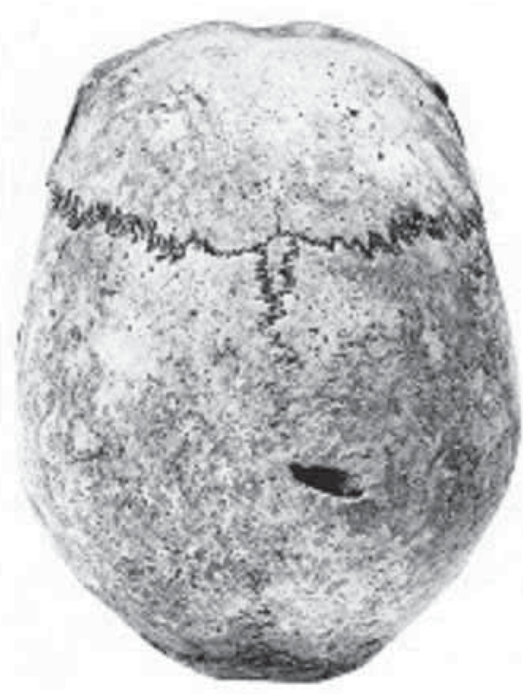

Bisko Poljanice br. 5/2

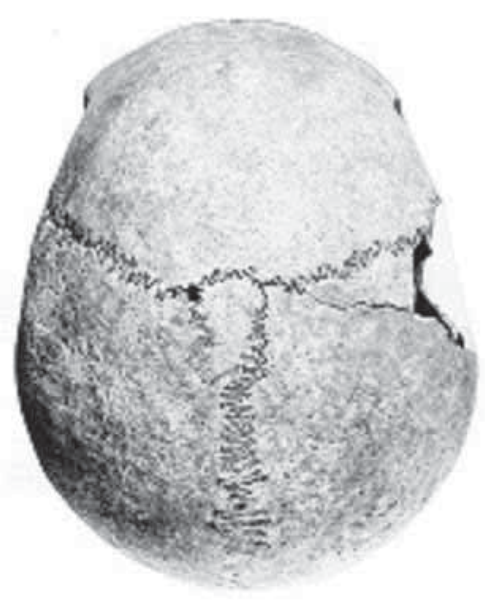

Lepenski Vir br. 30

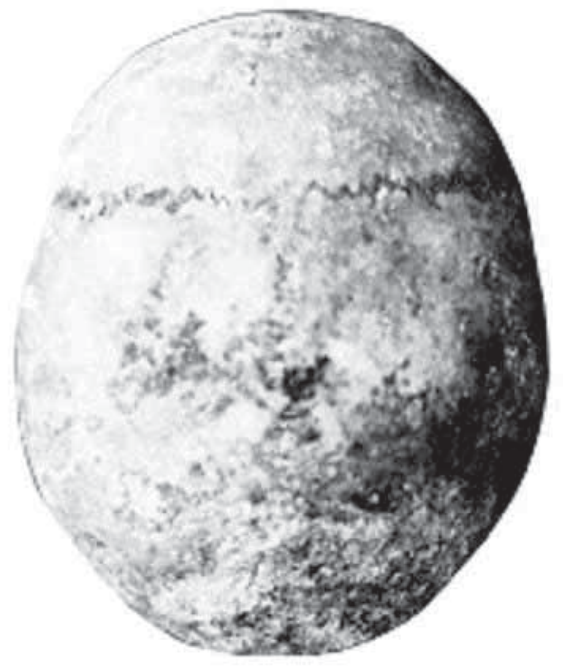

Arnautovići-Visoko br. 22

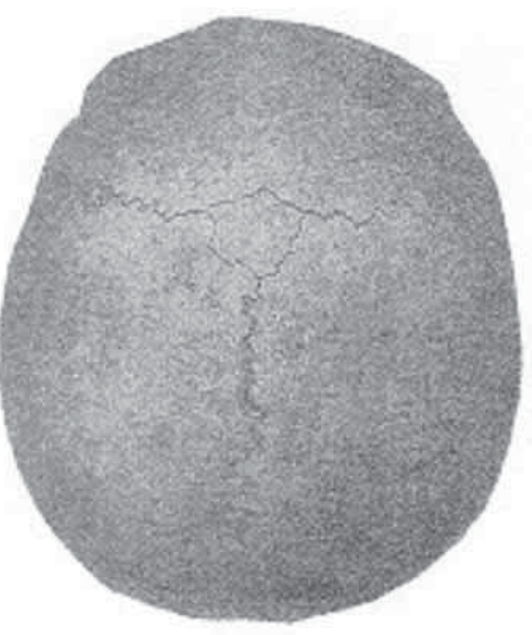

Tvrdoš-Trebinje br 65

Table II 